\title{
"Black Balts" Abroad: White Racism, Homosexuality and (Non-)Tolerance in Lithuanian and Latvian Emigration Narratives
}

\section{LAURA LAURUŠAITÉ}

\begin{abstract}
The present article will use the method of literary imagology in order to study the $21^{\text {st }}$-century Lithuanian and Latvian (e)migration literature and experiences in the context of racial, sexual, and cultural otherness. It will discusses marriage to a foreigner as something more than an official legitimation of one's love for a person of other ethnicity, the introduction of foreignness into the world of one's own culture, and the ideological penetration of the other into that which is inherited, ordinary and familiar. Provinciality, intolerance, and inability to admit and accept the Other or perceive oneself as a sexual Other remain an important part of Lithuanian and Latvian identity. In turn, emigrants in the host communities are a minority with counter-negative images, especially social ones.
\end{abstract}

Keywords: literary imagology; Lithuanian emigration literature; Latvian emigration literature; intolerance; homosexuality; stereotype; white superiority; identity

The paper below will outline the gender, racial and social identities attributed to marginal and non-conventional minorities, which are particularly susceptible to stereotypical approaches and are receptive to labeling. The engagement of the theoretical mode of literary imagology opens up a broad perspective of the $21^{\text {st }}$ century (e)migration texts, bringing to light a variety of psychological, moral and ethical dichotomies: the permissive and the unacceptable, correctness and vulgarity, narrowness and expansion, submission to stereotypical norms and liberation from frames of normativity. Lithuanian and Latvian (e)migration literature, which the paper employs as research material, problematizes such concepts relevant to imagology as provinciality, conservatism, gender, race, tolerance, imaginary power, white advantage, and the relations between body and identity.

\footnotetext{
1 "Black Balts" is designed as a play upon words, translating literally as "black whites",
} since the words "baltas" (Lith.) and "balts" (Latv.) mean "white" in the Baltic languages. 
The (e)migration literature has been penetrated by the segments of society and marginal groups and practices that have been poorly exhibited in Lithuanian and Latvian literature until now, and were marginalized before. Writers share their personal experience stories, and while this is an emotionally connotated and challenging topic, social reports conveyed in a literary form serve as a unique laboratory of ideological struggles, which helps to clarify dominant and conflicting patterns of sexuality and ethnicity. Literature encourages one to think about the ways in which negotiations on conservativeness and openness create new imperatives of Lithuanian and Latvian experiences, and the ways in which they shift the Baltic national character and national portrait formants. By raising such topics, emigration writers themselves are testing and questioning the limits of readers' tolerance.

In the words of Manfred Beller, the authority on imagology, "The importance of toleration for imagology lies in its relation with its mirror and counterpart, intolerance" (Beller 2007: 438), thus the article will discuss not only the dynamics of tolerance and intolerance, but also the various degrees of non-acceptance - from intolerance to hatred. Reviewing the forms of expression, causes and methods of intolerance, the paper explores the ways in which regulative mechanisms and social habits are shaping prejudices, and the ways in which these attitudes change. The task of the critical reflection by the imagologist is to identify norms and cases of their transgression in literature.

On the one hand, the Baltic States are sufficiently racially and heterosexually oriented, and therefore still have many manifestations of essentialism - an attitude that is contrary to otherness; but on the other hand, they fall under the influence of global tendencies and the rhetoric of tolerance. Therefore, literature reflects not just the manifestations of intolerance for foreigners and dissentients, but also an attempt to emancipate from them. The secludedness of Lithuanian identity has become a clichéd, emotionally charged image, a collective mythology that can be derived from the relics of peasant mentality: xenophobia, a patriarchal attitude, anti-Semitism, and so on. We can assume that Latvians are more open due to the earlier influence of multicultural cities and the impact of Protestantism on the formation of their worldview.

A separate thematic group consists of sexual minorities who emigrate under pressure from a homophobic Lithuanian community, and a controversial relationship with them in emigration. In the context of imagologically analyzed homosexuality, we should remember the Queer theory, which confirms the disability of the stereotypical attitude and liberation from norms: "Queer is a provocative policy that expands and deconstructs the limits of liberal tolerance and emphasizes the importance of differences. This policy opposes 
LAURUŠAITĖ

stereotypes and forced sexuality categories, and recognizes the diversity of sexual expression and the volatility of sexual identities." ${ }^{2}$ (Tereškinas 2007: 75)

In my opinion emigrants who find themselves in diverse and fluid foreign communities should improve their skills of communication with people of other ethnicities, gain representative flexibility, and expand their tolerance territories as they come into contact with other ethnic groups economically and sexually, encountering freer cultural attitudes towards gender, rather than hold on to those attitudes that they have brought with them from Lithuania and Latvia, where the canon of heteronormative and racially pure relationships prevails.

(E)migration literature depicting racial or sexual minorities has not been studied in Lithuania or Latvia to date. Latvia has been publishing an interdisciplinary magazine Dzimtes konstruēšana ("Gender Construction”) since 2013 for analyzing gender study aspects, but gender as a research material has not yet been specifically adressed in (e)migration studies. Among Lithuanian scholars, the problem of gender, (homo)sexuality, and nationalism in Lithuanian literature and culture has been analyzed most thoroughly by the sociologist and cultural critic Artūras Tereškinas.

\section{"The Fascism of Normality"}

We can find the roots of intolerance in the Baltic folklore which captures the image of the foreigners created in the collective imagination and has preserved many contemptuous proverbs with regard to them. According to the ethnologist Laima Anglickiené, "Folklore helps us to see that people still repeat the same stereotypes today, both at the home level and at the higher levels of government and science, although during centuries, the world seems to have gone so far to bring nations closer together, and different cultures towards tolerating each other." (Anglickienè 2006: 7). The media is also actively involved in shaping the public opinion and consolidating stereotypes that fuel the fear of the other, which has negative social consequences.

In the case of people of other enthicities and dissentients, people of other religions or orientations, it is still a usual thing to rely on the binary opposition: us and Others. In a general sense, the aspect of tolerance also includes intolerance to the exiles themselves as Others - the renegades of the nation, the outsiders, the traitors who have left their country for the sake of a better life abroad. The concept of exile, or emigrant, is demonized, especially from the

2 All quotes are translated by Aleksandra Fominaite. 
point of view of repressive nationalism, which often even stigmatizes the different ones by fostering essentialism. Recently, Lithuanian culture critics have emphasized excessive political correctness and the all-encompassing standardization, which the Lithuanian theater director Oskaras Koršunovas has called "the fascism of normality" (2017), and which the writer Sigitas Parulskis has referred to as "positive discrimination" (2018: 197). This normalization discourse "makes many people feel like refugees. Beyond that line, there are not just war refugees, but all kinds of non-normative people.” (Koršunovas 2017) By pushing out the different ones, we construct a "utopia of a homogeneous community" that is based on "comfort politics" (Davydova 2013: 47), or an illusion of a state allegedly based on multiculturalism (ibid. 49). The repertoire of otherness-related literary images is very wide, ranging from sharp rejection in the Baltic States to the other extreme that is practiced in countries foreign to them - thoughtless correctness, caution and grotesque acknowledgment of the rights of the Other:

They have even started to "clean" the fairy tales. Now, Maria has heard on television that next year [in England], textbooks for seven-year-olds will no longer have a fairy tale about three pigs: some commission has decided that mentioning pigs could possibly offend students of Muslim faith. (Fomina 2011: 191-192)

As witnessed by Litwak Sam Yossman, who worked as an interpreter in the Lithuanian Embassy in Britain after the restoration of independence, Lithuanians soon noticed the English people's tolerance and sensitivity to gender differences and exploited it for their own needs:

Many of the newcomers from Lithuania asked the Refugee Center for political asylum as homosexuals who are exposed to risk in their native country. [...] As far as I can remember, nobody was denied. This is England. After shedding a few tears, the asylum seeker would receive not just the seal confirming that (s)he was allowed to live and work in Great Britain, but also a municipal apartment and financial assistance from the municipality as a victim of a different sexual orientation. (Yossman 2016: 325)

These examples illustrate the ways in which the ideology of normality can miserably degenerate into the imagology of normality, and thus be misused. We see a paradoxical crossroad of power where the expulsive fascism of normality and integrating political fear of that fascism collide. 
LAURUŠAITE்

The $21^{\text {st }}$ century stories testify to the fact that Lithuanians and Latvians who arrived abroad experienced their first confrontation with ethnic, sexual and subcultural otherness. Facing a racial difference in a taxi cab just after arriving in America is as follows:

The driver is a black man. [...] The palms of his hands are fairer, but he is all black, as if daubed with tar. (Lauciūtè 2001: 22)

The one who was driving us was a nigger with red palms and fingertips. It looked as if his skin was peeled down to the meat. I caught myself staring at his palm and turned my eyes away in abashment. (Jegelevičius 2006: 77)

A black person seen for the first time primarily impresses the speaker with his/her strangeness, causing not so much a shock or rejection as astonishment and curiosity that do not have a derogatory downside. But there are also some examples showing that any negotiation with black identity is impossible. Even articulated tolerance is often declarative and confined to surface rhetoric of tolerance. That which changes is only the linguistic expression that creates the illusion of normality, while the emotional content of the concepts and the inner attitude remain unchanged:

In front of me, there were some dozing niglets [melnpuikas], as Ivona called them. "Niggers", I was thinking then, but here I am now, used to saying "African Americans", "gays", "people with special needs". (Manfelde 2012: 10)

Literary narratives reveal intolerance to any kind of otherness, social groups that are vulnerable, have specific needs and are therefore understood as marginalized minorities: "(S)he had no tolerance for marginalized people: pregnant teenagers, former prisoners, mentally handicapped or simply homeless." (Grušaite 2010: 31). Not only the color of the skin, but also any other unconventional trait that derives from the definition of normality can be the cause of rejection. However, when one is physically confronted with otherness, it can eventually become accustomed to and domesticated as a norm. This strategy is reflected in Miliūtè character's encounter with subcultures. She recognizes her own emotions and struggles with her conservative identity:

Previously, when I was picking strawberries, I had accustomed myself to not be surprised: neither by the peculiarities of culture nor the appearance of people, but nevertheless my eyes would stumble over the abundance of tattoos and piercings. And those dreadlocks: clotted, long and very dirty, most with variously patterned ribbons and all kinds of jingles. Not speaking about those blue, 
red, and orange cockcombs and a variety of shapes in hair shaving: from the moon and even the star drawings to the Chinese characters. And those outfits - semi-Indian, semi-cowboyish. (Miliūtè 2015: 58)

Emigration characters find themselves in a complicated ideological situation between the fascism of normality fostered abroad on one side, and indoctrinated aggressive intolerance on the other. They perceive body color or other bodily or social "flaws" as a non-canon imprint, and a deviation from the "norm." In this way, their texts bring up the problematicity of the integration of Lithuanians and Latvians into British or American society which is multicultural in terms of color, religion, culture or sex.

\section{Racial hegemony and controversy as a regime of social relations}

From a Eurocentric point of view, the fairer color of the skin automatically allows Eastern Europeans to be categorized as a more desirable group of immigrants in comparison, for example, to African Americans. The pale-skinned, including Eastern Europeans, are generally considered to be hegemonically superior to other racial groups and are therefore privileged, because they are likely to have similar cultural values. Fomina invites us to critically rethink the defined frameworks of power and privilege of cultural and racial identities associated with the color of the skin by using the physiological responses of different groups, ages, and races to excrements: "newcomers, both the elderly and the young, the black and the yellow, as well as representatives of mixed races, are equally wincing when cleaning toilets" (Fomina 2011: 189). White women, though not mentioned in this sequence, are implicit, because they clean up the train latrines (Fomina 2011: 189) and change diapers of the elderly persons (Rykštaite 2013: 55). Despite the physical appearance that does not emphasize our difference from the autochthones of host communities, whiteness is rarely portrayed as a percept of privilege and authority. White and other labor immigrants from Eastern Europe are treated as cheap labor, and even without being black in racial terms, they are considered to be inferior beings - "social blacks", "menial workers with white skin and dirty souls" (Manfelde 2012: 47). This chromatic dichotomy is particularly eloquently coded in the novel by Laima Muktupavela Šampinjonu derība (The Champignon Testament) under the subheading "Black Balts at the Celts' Place". The "black Balts" coupling is thought to be a play upon words to emphasize white ethnicity, a fair skin color, and, at the same time, putting the whites into the category of the raggery, or the menial workers. The new status of the economic migrant as a "menial worker" 
is a socio-economic rather than racial definition, so it is possible to talk about the blackness of Lithuanians and Latvians as social racism and to identify the economic discrimination against the white race. Frequently they receive lower wages, are unemployed, have lower education and income, and suffer from violence. Black people are portrayed as having more social privileges than white (especially Eastern Europeans), who are socially presented as blacker than black: "Black people failed to endure - they ran away, and their place was occupied by Ukrainians and Lithuanians" (Križanauskas 2001: 199) and lower than the Asian arrivals from the "Third World": "The Filipino team worked before us in the nursing home. They were paid taxi costs for shopping in the city and paid a higher salary. [...] We were a cheaper option. We had no privileges at all" (Davaine 2010: 100). It is an inverted caricature of the black-and-white world that ridicules the self-prominence of the whites.

In his novel Stroika ar skatu uz Londonu (Stroika with a London View), Vilis Lācitis also depicts Latvians on a hierarchically lower step than blacks - the main character (the author's alter ego, whose name is Vilis) finds himself a job to work for a black man from Ghana; on seeing the Latvians dumpster-diving, the local African rappers, who drive the "Mustang", a luxury sports car, make fun of the view. Different-aged, social, racial and ethnic groups who have lived in London longer and consider themselves British, ridicule Eastern Europeans and treat them as inferiors. Despite the color of the skin, the local British in Britain are people of special status, while the arrivals find themselves at the bottom of the ladder. This type of behavior, where black people feel superior to white people, is called white racism or reverse discrimination in theoretical literature. By depicting the role reversal, emigrant authors problematize the concept of white culture as a dominant one, a stereotypical racial and social difference, and a deprecating attitude, showing that a black or Asian person can be not only the same as white, but also superior (the one who earns more money, and holds a management position).

In the Eurocentric representation system, the power of symbolic law is usually attributed to the white man, preferably an educated and rich one. $\mathrm{He}$ is considered a starting point and benchmark for authority and autonomy. By depicting white male subjects (a Lithuanian, a Russian, and a Brit) in Malaysia and Bangkok, Grušaitè ridicules this phallocentric and Eurocentric connotation as a fictitious projection of value: "We thought we were invincible, fuckin' messiahs who have arrived with their white skin, blue eyes and the First World arrogance" (Grušaitè 2017: 245). The white men are initially convinced of their superiority and omnipotence, but ultimately the imaginary nature of that power emerges when the locals kidnap and execute their friend, the cocky 
British journalist Kenny, who intervened in local politics. The death of their friend knocks the Europeans out of the safe perspective of elitism and epicenter and destroys the usual scheme of subordinated and dominant cultures.

White immigrants, for their part, give the nickname "babays" (Lithuanian: babajai) to the swarthy men (Indians, Portuguese, Pakistanis) who are living next door to them and are renting homes or shops (corner shops) (Areima 2007: 40, Čepaitè 2011: 109-127). Čepaitè notes that the British do not use the word "babay" and do not even understand it, so this cataloging image is used only by Eastern European immigrants, as an ideological opposition to emphasize their own prestige (a chapter of Čepaitès book is called "Each Lithuanian Has His/ Her Own Babay").

\section{Emigration as a Laboratory of Religious, Racial, and National Test(ing)}

An important motive in literary works questioning the stability of conservative cultural order and its models is a marriage between a Baltic woman and a foreign man of another race and confession (usually black or Muslim). Contemporary emigration literary works, referring to the introduction of blackness into the national body, speak of attachment or distance from the pure cultural code and tension, and of confrontation between openness to and closedness to otherness, which often expresses the positions of different generations. What manifests itself in this case is not disdain, but a phobic attitude towards racial or religious identity, and a stereotypical fear of the other: "The older women have a horror over the Arabic men who bring the gullible Latvian female doves out and into captivity. 'Now, watch yourself, just don't marry [him]!'” (Manfelde 2012: 108). In this case, the reference to the generation of "older women" is significant, because the image of a Muslim as a harmful kind of foreignness, which was being indoctrinated for many years, cannot be so easily erased from their experience. They imagine a Muslim as definitely a terrorist, who is determined to stone one to death even for eating pork (Rykštaitè 2013: 32). It is important to mention that Lithuanians were the last Europeans to accept Christianity in the 13th century, therefore religious conservatism is deeply rooted.

The attitude of the older generation is similarly hostile with regard to marriage to a black man, which, in terms of a conservative viewpoint, is contamination of one's own genetic substrate, and betrayal of ethnicity, thus "[...] grandmothers and grandfathers in Lithuania disavow their black grandchildren" (Fomina 2011: 160). However, the younger generation is already trying to avoid unwanted associations, at least on a rhetorical level: 
"How would your parents react to your foreign husband of a different race?" [thinking] Mom would get a heart attack, and dad would pull out a shotgun. - They would be very happy, - I replied. (Rykštaitè 2013: 96)

Emigration writers give a strong voice to the Baltic women who have chosen a racial Other as their partner. Such an introspective look is a convincing opposition to external critics who have not encountered this difference from a shorter distance. The following conversation between two emigrant girlfriends reveals interpretative stiffness and an inflexible approach:

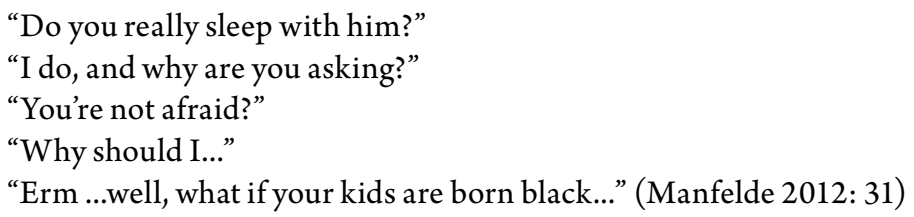

From the mouth of the girlfriend comes the voice of traditional worldview, which communicates the fear of normative discourse caused by the breaking of traditional bans and taboos. A black child appears as a depiction of tainted reproduction, because the baby, as an extension of the "I", must be of the same color.

The woman whom Aivars Kḷavis depicts in his book Likvidētie autobusi (The Liquidated Buses) is guided by the opposite programmable option - here, a woman's body (in a wider sense the body of Latvia) is depicted as a place of combination of black and white ethnicities. In the novel, the emigrant daughter returns home to her native Rāmgali village with her black son Ojo in her arms. In the context of the novel, the etymology of Rāmgali (translated from both Lithuanian and Latvian as a "calm finish point") is used ironically, because that calmness is disturbed by the global tendencies of racial blending. The village transforms into a field of change, a zone of a clash of the different approaches. The daughter responds to her father's questioning look (probably the father lacks words to verbalize his question) with an impersonal genetic argument, seeking not to stimulate an undesirable discussion: "Why is he black? Probably because the genes of black people are stronger than the genes of the white ones" (Kḷavis 2016: 318).

Ironically, the black baby is the only child in a dying village, from which all the people of reproductive age have emigrated to Riga or abroad, taking their children with them. The confrontation between the daughter, who has returned from England, and her father is taking place at the no longer functional bus stop on the outskirts of the village - a Latvian woman with a black child is admitted 
to the village, into the community, and enters the territory of Latvian person's consciousness. The introduction of black race into the local environment is not "imaginary", but rather, a practical test of the community on racial difference, and a crossing of the boundary by one's body. The black baby is thrown into the most unfavorable medium - the culturally and mentally isolated province of Latvia. In this way, Klavis not only challenges the desolation of Latvian villages, but also drastically revises the normative arguments of rural people, challenging the community's provincialism, stereotypical thinking and ideals. We can perceive this as a more universal metaphor that the neatly structured and secluded world of Latvia and the persistence of everyday life is illusory, and that eventually, penetration of otherness will take place. On the other hand, there are two variants of compassion, two areas outside the power network that collide with each other - the peripheral black identity in the peripheral Latvian rural environment. The book ends with this image, leaving the issue of integration and tolerance open. After challenging the limits of the reader's openness, the book invites us to consider the possibilities of feasibility and realization of "blood transfusion" as a positive aspect of racial mixing.

In her book Cukruota žuvis (Sugarcoated Fish), Audronè Urbonaitè likewise appeals to provincialism, this time of the Lithuanian people. She fears that Lithuanians are wrongly identifying threats because she has her own bitter experience - "globalization which is chirping in the kitchen" (Urbonaite 2012: 194), i.e., she is raising her Chinese granddaughter in Lithuania. Urbonaite calls herself a "weak-blooded white woman" (73), having in mind a weak European gene that, in the nearest future, will be overcome by the stronger genes of the yellow race that have matured in the setting of long-lived Chinese civilization. In this way, Urbonaite ridicules the narrow, Eurocentric-oriented Lithuanian approach, which we no longer notice in "turning around our own cooled-off navel" (31) and suggests introducing a compulsory globalization vaccine into health centres (240). She speaks of an intercrossed world where tapatybe.lt (identity.lt) will not live long, and the Slavs of the Baltic States will "painlessly dissolve in yellow blood." In the discussion on race, she introduces the third color - yellow - into the black-and-white dichotomy. Urbonaite ironically proposes to populate the dissolving Lithuania and the thinned-out city of Vilnius with Chinese people to enrich the gene pool (115). Klavis and Urbonaite, with their globalist visions and interpretations, are designing the future and expanding the concept of essentialistically perceived contemporary Lithuanian and Latvian identities.

Literary works show the image of a Lithuanian person who is intolerant of people of both his/her own nation and foreign ones. The publicist Laima 
Lavaste, in her book Mes. Lietuviai. Vadovelis kaip suprasti lietuvius ir jais naudotis (Us. Lithuanians. A Textbook on How to Understand Lithuanians and Use Them), simply desecrates the national image of a Lithuanian person by ridiculing the Lithuanians' provincialism, peasant roots and attachment to their own land - on the cover of the book we see a somewhat portly Lithuanian who is drowsing in the local swamp of his backyard. We can make a guess that behind this ruthless criticism of one's own people lies the lack of national selfesteem and the desire to appear superior by disavowing the habits and lifestyle of one's fellow-countrymen. When social groups or collectives feel intimidated and less tolerated by other cultures, negative thinking about themselves reduces their responsibility for potential failure (Lehtonen 2005: 82).

\section{Articulations of Sexual Identity}

Another important aspect in the context of intolerance is homosexuality, faced with resistance as an alternative practice. (E)migrant texts can reveal a lot of homophobic attitudes that attribute unconditional sexuality to the category of "abnormality" or "second-ratedness", although externally, people attempt to convey a tolerant attitude. The negatively represented aspect of homosexuality is particularly characteristic of the texts by Lithuanian emigrants. We should emphasize that this approach has a historical and social basis, as Lithuania was the last of all the Baltic States to cancel punishment for homosexual relations: "The article of the Criminal Code punishing consensual sex between two adult men was abolished as late as in 1993" (Tereškinas 2002: 183), while in terms of sexual intolerance, Lithuania is metaphorically called a "country of multiple Gražulis" (Tereškinas 2013: 115). While the presentation of the Lithuanian show at Eurovision in 2014, which ended with kisses between two women and two men, tried to confirm Lithuania's freer attitudes to homosexual relations in the eyes of other countries, in Lithuania itself it caused a heated debate on the promotion of homosexual relations.

Petras Gražulis is a former member of the Lithuanian Parliament (Seimas) and a fierce fighter against homosexuals who has become notorious for his drastic statements and attacks during gay marches. He has given a pair of jeans with a hole in the back as a present to defenders of sexual minority rights. The Lithuanian Gay League (LGL) have decided to sell this garment - a gift from a politician who is strongly criticizing them at an auction, and to allocate the money for the cause of fighting for equality. 
Literary statements (e)migrants make are often characterized by an anti-gay attitude which is expressed in a hateful, insulting and aggressive manner and is charged with uncensored rhetoric of swear words:

"How can this be done? A man into a man - for fuck's sake - the very thought is disgusting ... And the meaning of all this? Where's the point to tolerate, holy balls?" (Ivaškevičius 2012: 57)

This example summarizes the attitude of an "average" Lithuanian towards persons of different orientation, despite the slogans of tolerance indoctrinated by the official institutions and media in Lithuania and the implemented policy of integration. Such a categorical statement is reminiscent of comments in electronic media that promote intolerance, creating a living environment for social dissatisfaction. Here we can recall the fact that the theory of imagology attributes to literature the function of generating stereotypes, thus such statements, reflecting social reality in artistic narratives, can even deepen the gender disagreements, the more so as the play Išvarymas (Expulsion) was staged in Lithuanian, Latvian and Estonian theaters and played to full houses. On the other hand, we can assume that by placing radical and offensive statements into the mouths of the characters, the writers actually convey the criticism of racist or nationalistic ideology, but it is likely that not all readers / viewers can sense this ethical implication.

Lithuanian emigrant writers choose to talk about non-traditional orientation as an impulse to emigrate because they feel "unwelcome" in, and inconvenient to, their native country. Their novels raise the problem that Lithuania does not accept homosexuals as an integral part of society. They leave for multicultural cities abroad where public attitudes are more liberal and more tolerant of the diversity of sexual orientations. We can consider them "gender emigrants" because of the discrimination and discomfort it produces. This is a new category in the exile scale. People leave for other countries because of being incapable of fitting into the frameworks of normality and heterosexuality: "I departed to America to conceal my sexuality", says Linas Jegelevičius in his novel Nuogas prieš jus (Naked In Front of You) which actualizes the concepts of shame and guilt important to imagology in the context of masculinity (Jegelevičius 2006: 199). By the very title of the book the writer communicates a message that in his text we will be confronted with the exposure to his sexual self-image. It is only after he has left for multicultural America that he dares to try and free himself from the obedience that disciplines his body and consciousness by initially depicting unconventional folks, and gradually 
making public his own non-normative sexuality. However, it is clear that the Lithuanian emigrant takes his cultural values and indoctrinated beliefs with him and they prove difficul to get rid of. The consequence of silent and longterm discrimination is his own denial of his sexual orientation, his belief that "homosexuality is a sin" (205), a perversion, an immoral and pathological form of sexuality. It is also necessary to consider intolerance in Soviet times when the author read the textbook by the Latvian sexologist Jānis Zālītis Mìlestîbas $v \bar{a} r d \bar{a}$ (In the Name of Love) which depicted sexual relations between samesex persons as a reprehensible physical pathology to be medically treated (46).

While in Lithuania, the author had existed in the underground, at the periphery of power. Now, as an emigrant, he finds himself in the center of power - a paradise of homosexuals, transsexuals and transvestites in South Beach, Miami where the otherwise marginalized homosexual identity is perceived as the norm and where "without any disturbance, you could be whoever you want to; here is probably the only place in the world where the minority has turned into the majority of society" (258). The guy from a "conservative country" (204) mixes with a crowd of his "fellow men": he gets a job as a security guard at a gay club, acts in gay porn movies, but is still shy of his orientation, limits his sexual expression, and disguises himself with all kinds of double and behind-the-scenes identities. He feels embarassed even speaking on this topic, pretends to be heterosexual (by maintaining a "normal" relationship with a woman) or generally asexual (by abstaining from any sexual relations for two years). In pursuit of not only sexual but also national anonymity, the protagonist conceals the fact that he is Lithuanian (he pretends to be Russian) and uses a pseudonym, his so-called "stage name" - Sasha. His coming out takes time. He deconstructs himself so that he can re-construct himself. His identity is inactive and fierce, so it is not liberating (him). Throughout the process of his search for identity, Jegelevičius tries to identify public attitudes that condemns a person with a different sexual orientation, and to disclose the long-term damage of stereotypes to the human psyche.

The protagonist of Jolita Seredaitès book Auksinis berniukas (Golden Boy), Karolis, also falls into the category of non-traditional orientation. Like Jegelevičius's character, he pretends to be "straight" and disguises his orientation by falling in love with his sister, until eventually this love turns into a pathological attachment. Having experienced isolation and failing to find a place in Lithuanian society, Karolis emigrates to America, becomes infected with HIV and dies (Seredaite 2006: 236). He also perceives homosexuality as a social ailment or illness, and sees himself as a loser and pervert, therefore he accepts death as a well-deserved punishment. This narrative solution is 
ideologically significant, because it emphasizes gayness as an unwelcome and disturbing agent in society. The fact that the great love of his life - an American man called Gregor from New Orleans - is a deaf-and-dumb person symbolizes the social distance of gay people, their separation from the normative majority and inability to communicate their experience and needs.

Unlike the works discussed above, Grušaitës novels depict same-sex love (a lesbian relationship in Neišsipildymas/Unfulfillment, and a man's love for a man in Stasys Šaltoka: Vieneri metai/Stasys Šaltoka: One Year) as a legitimate expression of sexuality. The vision of sexual (self-)emancipation organically fits into the paradigm of freedom, dialogue, and tolerance which Grušaite promotes. She emigrates because the nation state as a moral body and social power in her opinion over-regulates various orientations, choices and values. Fighting for a different image of minorities, Grušaitè also fights for a different Lithuanian image abroad. We can guess that she conceives of those "projects" of the same-sex relationships as a provocative gesture against the canon of repressive nationalism. The characters of alternative sexual orientation whom Grušaite depicts do not match the limits of the proposed normality, and do not correspond to the socially established standard of gender and sexuality, therefore they are pushed out of the dominant sexual culture in Lithuania. Rugile and Ugnè, the protagonists of Unfulfillment, choose cities (London, Paris, Barcelona) that promise them anonymity and dissolution in the cosmopolitan crowd. The book deliberately seeks to provoke the sensitive Lithuanian society and to protest against its sterile social order by critically articulating the narrow attitudes and prejudices. Despite the fact that the society is determined to burn them "at the witch's stake at Lukiškès square" (Grušaitè 2010: 11) not only for declaring their lesbian orientation but also for their denial of traditional values in general, the characters do not allow others to construct their identities, refuse to imitate heteronormativity and actively create their own (hi)story. This is the attitude of a generation which has no direct experience of the Soviet era.

In Grušaitè's novel Stasys Šaltoka: One Year the topic of homosexuality is subdued and associated not so much with the bodily relationship as with the friendship between men. Grušaitè explains this attitude as follows: "In the novel, I deliberately have not developed the topic of sexuality, because there is too much of it - of all kinds of sexuality - in the contemporary world and literature. I was more concerned with friendliness, in the way in which a person who doesn't feel any connection to other people and homeland eventually discovers a somewhat warm connection to a male friend. It is no coincidence that the novel begins with a coldish sex scene and ends with a sense of warmth." (Grušaitè 2017) In contrast to Linas Jegelevičius's protagonist who is constantly 
experiencing a crisis of identity, the characters of Grušaitè's novels are freer to practice love between two men or two women in search of their true selves. The homosexual identity that Grušaite establishes in her works is liberated and natural, while in Naked In Front Of You it is problematic, schizophrenic, and driven by blame and shame. Repressed sexuality cannot unfold freely even on the world stage.

The contribution that Paulina Pukytè makes is also important in the debate on sexuality because it challenges the double identification of the arrivals from Eastern Europe and the fragmentation between the external slogans of tolerance and inadequate self-representation:

[The Polish man] stretches out his hand to my friend [Lithuanian man] and, even before saying his own name or asking for his one, wonders:

- Are you gay? [...] I'm asking for no specific reason. I've never seen a live gay. I'm friendly.

In a word, here are the new Europeans. How are the old ones going to treat them? Will they re-educate them?

Then he says to me:

- And you, are you a lesbian? There's nothing wrong with that, I'm just asking. [...]

Then I tell him:

- You know, you yourself look very similar to gay.

And that is true, it's just that he doesn't realize it. To him, these words are like a red rag to a bull [...] (Pukyte 2005: 32)

Initially, they are trying to treat a negative stereotype positively, but the inadequacy of stereotyped internal attitudes and external rhetoric are revealed when the Pole uses sexual characterizations lightly. When someone else calls him gay in the same way, he takes it as an insult. Obviously, after arriving at a sexually free country, post-Soviet agents get imagologically fragmented. They want to mimic openness but having never encountered sexual otherness before they overdo it because their disciplined worldview contradicts it. This discrepancy is grotesque because the internal self cannot be artificially redesigned according to the British standards of sexual democracy and the demonstrative rhetoric only reveals further the homophobic attitude of an Eastern European. There is a gap, an abyss that opens up between depicting and imagining. From the observer's distance, Pukyte ironises the clash between these two cultures - that of openness and that of seclusion - by introducing the distinction between the "new" and the "old" Europeans, focusing on the new ones as yet immature, underdeveloped in the meanings of tolerance, and 
attributing the role of a patient teacher and the educational mission to the old ones.

There are examples that testify to the fact that direct encounter and communication with sexual minorities help to promote openness. The protagonist of Rykštaitè's novel Kostiumu drama (Costume Drama), who is sharing a squat with a gay man and sees the love between men from up close, opens up dialogically and accepts it as a normal part of a daily life. In Ina Pukelytè's consciousness, the rooted visions of homosexuals as deviants and perverts correct themselves after a visit to a gay club in France: "It was the first time she stepped into the homosexual territory and it seemed to her that she would see something obscene right now. Unfortunately, she had to be disappointed [...] She was looking around, sipping the delicious drink and smiling. She also saw the smiling faces around her, for a moment it appeared to her that she found herself in paradise" (Pukelytè 2000: 104-105). Initially, the protagonist succumbs to a strategy of stereotyped visualization, associating homosexuality with debauchery and the exotic and expects to see something unauthorized, but the actual experience adjusts her approach and changes the representation policy. Having imagined the gay club as hell, she leaves it thinking it a paradise.

\section{Conclusion}

The analysis of manifestations of conservatism and tolerance complements the Lithuanian and Latvian national self-portraits with new features. The books written by emigrants reveal a complex relationship between ideological openness and secludedness: the desired freedom and conservatism, the controversy between (denied) patriotism and (yet unrecognized) values of internationality, and a conflicting relationship between stable continuation and interruptions of sexuality and ethnicity. However, the aspects examined are selective and far from exhausting the complexity and controversy of this phenomenon.

It should be stated that Lithuanian and Latvian (e)migration literature reflects quite inflexible attitudes towards otherness. Lithuanians remain ideologically secluded and hardly open to the variety of experiences and identities. In most cases, they reject the Other (black, Muslim, homosexual) as unfamiliar and strange, even without reflecting on the reasons for that hostility.

The assumption that Eastern Europeans, when faced with strangeness and otherness, widen their tolerance limits, has been proven only partially, because isolation and stagnation brought abroad as the acquired mental and social baggage is the dominant paradigm despite the multitude of externally 
encountered identities. The incisions of xenophobic images settled in the collective set of images (imagery) are so powerful that the different standards of socio-cultural reality are not always capable of moving them. The thinking of most of the protagonists is characterized by a slighter or stronger tendency towards homophobia. Multiculturalism is often treated as violating the dominant paradigm of sexuality or ethnicity rather than enriching it.

Only in exceptional cases the otherness is tested for exoticism (women choose a black or Muslim partner). In most cases, black people in the Baltic immigrants' system of values are treated as marginal, but there are occasions where racial Others find themselves at a higher level of the social hierarchy (occupying higher positions, receiving higher salaries, or even becoming employers).

In emigration, Lithuanians and Latvians often feel weak and socially underprivileged, so writers give them a voice of the racially "privileged" whites. They enjoy their right to speak but expose themselves as provincial because they tend to speak from the righteous position, use open sexual and racial rhetoric (gay, nigger) lightly, and try to demonstrate their moral advantage by scorning the Other. Such a humiliating tone indicates their own traumatized (depreciated) self, when, by ridiculing black or homosexual people, they suppress the perception of themselves as the Other and thus allegedly break free from the victim's complex. An attack becomes a defensive shield.

We can state that the theme of otherness in the literary works is twoway - Lithuanians and Latvians emigrate striving to liberate themselves from subordinate roles and what reaches their homeland is the product of globalism - black children. Compared to Lithuanian examples, Latvian (e) migration literature displays a smaller number of openly hostile statements and they do not consider the aspect of homosexual relations as a push factor for emigration, so we can assume that a more liberal spirit of Protestantism and multiculturalism allows Latvians to cultivate their sexual identity more freely in their homeland, and therefore it is less repressed.

The analyzed examples testify to a sufficiently stable panorama of racial and sexual recognition and belonging which is marked by conservatism but is gradually changing and gravitating towards tolerance. It is possible to identify a certain change in attitudes because there is more than a decade separating the books in question. The younger generation which has grown up in the time of independence has more cultural receptivity and is characterized by a more cosmopolitan imagination that helps them avoid gender stereotypes or at least emancipate from them. 
"Black Balts" Abroad

\author{
Laura Laurušaitė \\ laura@llti.lt \\ Lietuvių literatūros ir tautosakos institutas \\ Antakalnio St. 6 \\ LT-10308 Vilnius \\ LIETUVA / LITHUANIA
}

\title{
Works Cited
}

Anglickienè, L. 2006. Kitataučiu įvaizdis lietuviu folklore. Vilnius: Versus aureus.

Areima, M., 2007. Nostalgija. Vilnius: Lietuvos rašytojų sąjungos leidykla.

Beller, M. 2007. Toleration/Intolerance. - M. Beller, J. Leerssen, eds., Imagology: The Cultural Construction and Literary Representation of National Characters. Amsterdam-New York: Rodopi, 437-441.

Davainè, E. 2010. Airija: tolima artima sala. Vilnius: Baltos lankos.

Davydova, D. Tautos paraštès ir nepatogūs pilietiškumai. - L. Žigelytè, ed. Tautos paraštés ir nepatogūs pilietiškumai. Vilnius: Žiemos žodžiai, 41-57.

Fomina, A. 2011. Mes vakar buvom saloje. Vilnius: Kitos knygos.

Grušaite, G. 2010. Stasys Šaltoka: Vieneri metai. Vilnius: Baltos lankos.

Grušaitè, G. 2017. Neišsipildymas. Vilnius: Lapas.

Grušaitė, R. 2017. Svetur veržiasi ir Gabija Grušaitė, ir jos romanas, ir knygos herojus. - https://kultura.lrytas.lt/literatura/2017/11/21/news/svetur-verziasi-ir-gabijagrusaite-ir-jos-romanas-ir-knygos-herojus-3584577/?utm_source $=$ lrExtraLinks \& utm_campaign=Copy\&utm_medium=Copy $(11.04 .2019)$.

Ivaškevičius, M. 2012. Išvarymas: vieno obuolio kronika. Vilnius: Apostrofa.

Jegelevičius, L., 2006. Nuogas prieš jus. Panevėžys: Magilè.

Kaunaitè, U. 2015. Žmonès iš Alkapés. Vilnius: Žara.

Kḷavis, A. 2016. Likvidētie autobusi. Rīga: Zvaigzne ABC.

Koršunovas, O. 2017. Režisierius O. Koršunovas: įsigali normalumo fašizmas. http:// www.delfi.lt/veidai/kultura/rezisierius-o-korsunovas-isigali-normalumo-fasizmas. $\mathrm{d} ? \mathrm{id}=73904000$ (03.04.2019).

Kota, L. 2016. Mierielas vilkme. Rīga: Dienas grāmata.

Križanauskas, A. 2001. Nakvynés namai Londone. Vilnius: Tyto alba.

Lācītis, V. 2010. Stroika ar skatu uz Londonu. Rīga: Mansards.

Lauciūtè, A. 2001. Barakudos dienoraštis, arba lietuvaitès įspūdžiai Kanadoje. Vilnius: Spauda.

Lavastè, L. 2012. Mes. Lietuviai. Vadovélis kaip suprasti lietuvius ir jais naudotis, Vilnius: Tyto alba.

Lehtonen J. 2005. Stereotypes and Collective Identification. - D. Petkova, J. Lehtonen, eds. Cultural Identity in an Intercultural Context. Jyvaskyla: University of Jyvaskyla, $67-94$ 
LAURUŠAITE்

Manfelde, A. 2012. Dzimtenìte. Rīga: Literatūras kombains.

Miliūtè, J. 2015. Ar braškès virsta ferariais? Vilnius: Obuolys.

Multupavela, L. 2003. Pievagrybiu testamentas. Vilnius: Mintis.

Parulskis, S. 2018. Amžinybè manęs nejaudina. Vilnius: Alma littera.

Pukelytè, I. 2000. Prancūziškas romanas. Vilnius: Tyto alba.

Rykštaitè, V. 2013. Kostiumų drama. Vilnius: Tyto alba.

Tereškinas, A. 2002. Viešumo ịkainiai paraštėse: Seksualinių mažumų vaizdavimas Lietuvos spaudoje (2000-2001 metai). - A. Tereškinas, ed. Vieši gyvenimai, intymios erdvès: Kūnas, viešumas, fantazija šiuolaikinejje Lietuvoje. Vilnius: Baltos lankos, 181-201.

Tereškinas, A. 2007. Ese apie skirtingus kūnus: Kultūra, lytis, seksualumas, Vilnius: Apostrofa.

Tereškinas, A. 2013. Jaustis nepatogiai, jaustis queer. - L. Žigelytè, ed. Tautos paraštès ir nepatogūs pilietiškumai. Vilnius: Žiemos žodžiai, 109-116.

Yossman, S. 2016. Šaltojo karo samdinys. Vilnius: Mažoji leidykla. 